\title{
Genetic Variability in Regenerated Metarhizium flavoviride Protoplasts
}

\author{
Júlia Kuklinsky-Sobral $^{1 *}$, Elza Áurea de Luna-Alves-Lima ${ }^{2}$, Janete Magali de Araújo ${ }^{3}$ and \\ João Lúcio Azevedo ${ }^{1,4}$ \\ ${ }^{1}$ Departamento de Genética; Escola Superior de Agricultura "Luiz de Queiroz"; Universidade de São Paulo; \\ 13400-970; Piracicaba - SP - Brazil. ${ }^{2}$ Departamento de Micologia; Universidade Federal de Pernambuco; \\ 50670-901; Recife - PE - Brazil. ${ }^{3}$ Departamento de Antibióticos; Universidade Federal de Pernambuco; \\ 50670-901; Recife - PE - Brazil. ${ }^{4}$ Núcleo Integrado de Biotecnologia; Universidade de Mogi das Cruzes; \\ jksobral@esalq.usp.br; Mogidas Cruzes - SP - Brazil
}

\begin{abstract}
Protoplast isolation and regeneration were evaluated in two wild-type and two colour mutant strains of Metarhizium flavoviride. Cultivation in liquid medium, followed by mycelium treatment with Novozym 234 in the presence of $\mathrm{KCl} 0.7 \mathrm{M}$ as osmotic stabilizer, produced $5.05 \times 10^{6}$ to $1.15 \times 10^{7} \times \mathrm{mL}^{-1}$ protoplasts. The percentage of regeneration ranged from 6.65 to $27.92 \%$. Following protoplast regeneration, one strain produced spontaneously stable morphological variant colonies. Although colonies with altered morphology have been reported in bacteria following protoplast regeneration, this is the first time that the same is described in a filamentous fungus. The original strain and one derived variant were tested for sensitivity to the fungicides benomyl and captan.
\end{abstract}

Key words: Metarhizium flavoviride, protoplasts, genetic variability, Benomyl, Captan

\section{INTRODUCTION}

The entomopathogenic fungus Metarhizium flavoviride Gams and Rozsypal has great interest since it has been used in biological control of insect-pests, mainly grasshoppers, locusts (Goettel et al., 1995; Inglis et al., 1997; Magalhães et al., 1997; Lomer et al., 2001) and also to control the bovine tick Boophilus microplus (Athayde, 2002; Onofre et al., 2001b). The study of natural or induced genetic variability is one of the first steps for the development of fungal genetic breeding programmes. In programmes that evolve entomopathogenic fungi is fundamental to obtain strains, which, besides high conidia production, easy dissemination and biological control efficiency, have genetic defined markers as morphological and auxotrophic ones and resistance to fungicides, among other characteristics (Azevedo, 1995). This will allow settling crosses that could result in improved recombinant segregants combining favorable characteristics from the two parental strains used to perform the crosses.

Parasexual cycle permits genetic analysis of Deuteromycetes or Imperfect Fungi. However, heterokaryon production between some strains is not always possible due to the presence of genetic incompatibility factors. In these cases, protoplast isolation and fusion is a way to overcome genetic incompatibility, allowing crosses between incompatible strains. Protoplast

*Author for correspondence 
fusion was already used for crosses between strains of entomopathogenic fungi as Metarhizium anisopliae and Beauveria bassiana (Silveira and Azevedo, 1987; Paccola-Meirelles and Azevedo, 1994). In M. flavoviride, several different prototrophic wild-type strains besides morphological and auxotrophic strains are already available (Onofre, 2001; Kuklinsky-Sobral, 1999) and its parasexual cycle has recently been described (Onofre et al., 2001a; Figueiredo and Silva, 2001; Muniz et al., 2001). So, practically all conditions are available to settle genetic breeding programmes in this species. However, as occurred in other fungi, incompatibility problems may present difficulty to perform some crosses. In this way, the aim of the present research was to establish appropriated conditions to isolation and regeneration of protoplasts from $M$. flavoviride in order to make possible recombination between incompatible strains. The occurrence of variant colonies with altered morphology detected after protoplast regeneration was also investigated and natural resistance to two fungicides was analyzed in a wild-type and in one of such variants.

\section{MATERIALS AND METHODS}

\section{Strains and Culture Conditions}

Two wild-type strains of Metarhizium flavoviride, designated CG423 (syn. Metarhizium anisopliae var. acridium), isolated from Schistocerca pallens Thunberg - Orthoptera: Acrididae - in the State of Rio Grande do Norte/Brazil, and CG366, isolated from Ornithacris cavroisi Finot - Orthoptera: Acrididae - in Nigeria) were used. They were kindly provided by the Entomopathogenic Fungi Laboratory at CENARGEN/EMBRAPA/BRAZIL. Two morphological mutants derived from the wildtype strains and obtained by ultra-violet irradiation (Kuklinsky-Sobral, 1999) were also used. Table 1 shows the phenotypic characteristics of the used strains. Liquid and solid Complete Medium (CM) as described by Azevedo and Costa (1973) were used. Incubation temperature was $30^{\circ} \mathrm{C}$.

Table 1 - Strains of Metarhizium flavoviride used.

\begin{tabular}{lc}
\hline \multicolumn{1}{c}{ Strain } & Phenotype \\
\hline CG423 (wild-type) & Green conidia \\
423ylo (morphological mutant) & Yellow conidia \\
CG366 (wild-type) & Green conidia \\
366vio (morphological mutant) & Violet conidia \\
\hline
\end{tabular}

\section{Protoplast Formation}

Conidial suspensions in aqueous solution of Tween $80(0.1 \% \mathrm{v} / \mathrm{v})$ were prepared from ten days old cultures grown on solid CM to obtain $2 \times 10^{6}$ conidia $\times \mathrm{mL}^{-1}$. Flasks containing $50 \mathrm{~mL}$ of liquid $\mathrm{CM}$ were inoculated with $1 \mathrm{~mL}$ of this suspension and incubated for $48-72 \mathrm{~h}$ in static way. The mycelium was filtrated and washed twice with $\mathrm{KCl}$ 0.7M (phosphate buffer $\mathrm{pH}$ 5.8) as an osmotic stabilizer. The enzymatic treatment was performed for 3 hours under gentle shaking ( $80 \mathrm{rpm})$, adding for each $\mathrm{mL}$ of $\mathrm{KCl} 0.7 \mathrm{M}, 5 \mathrm{mg}$ of Novozym 234 (L-2265 - SIGMA) and 50mg of wet mycelium. Following this stage, the suspensions were centrifuged for 30 seconds at $40 \mathrm{~g}$ and the supernatant recovered and centrifuged for 10 minutes at $1500 \mathrm{~g}$. The resultant pellet was resuspended twice in $\mathrm{KCl} 0.7 \mathrm{M}$ and centrifuged for 15 minutes at $1500 \mathrm{~g}$. Finally, the pellet was resuspended in $3 \mathrm{~mL}$ of $\mathrm{KCl} 0.7 \mathrm{M}$. The estimated number of protoplasts formed per milliliter of osmotic stabilizer was estimated using a Neübauer chamber.

\section{Protoplast Regeneration}

Serial dilutions of protoplast suspensions were made in distilled water and in $\mathrm{KCl} 0.7 \mathrm{M}$ and plated $(0,1 \mathrm{~mL})$ on solid $\mathrm{CM}$ and solid $\mathrm{CM}$ supplemented with $\mathrm{KCl}(0.7 \mathrm{M}$ final concentration) $+5 \mathrm{~mL}$ of semi-solid $\mathrm{CM}$ supplemented with $\mathrm{KCl}(0.7 \mathrm{M}$ final concentration), respectively (Silveira and Azevedo, 1987). They were incubated for 10 days. The regeneration frequency was calculated according to Shimizu and Kurizu (1987).

\section{Resistance to Fungicides}

The fungicides benomyl (Benzimidazole i.a.50\% Du Pont) and captan (Ftlalimide i.a.50\% - Fersol) were dissolved in DMSO (Dimethyl sulfoxide Merck) at $10 \mathrm{mg} \times \mathrm{mL}^{-1}$ and added to $\mathrm{CM}$ at $45^{\circ} \mathrm{C}$. The fungicide concentrations ranged from $0.8 \mu \mathrm{g} \times \mathrm{mL}^{-1}$ to $102.4 \mu \mathrm{g} \times \mathrm{mL}^{-1}$ of medium culture. Conidia were inoculated onto the center of Petri dishes contained the culture medium supplemeted with the fungicide. After ten days incubation, the diameter of the growing colonies was measured. Three plates were used per treatment. The averages were evaluated by analysis of variance and Tukey Test. 


\section{RESULTS AND DISCUSSION}

The number of protoplasts formed and regeneration percentages for the tested strains are in Table 2. The results showed that the use of the same enzymatic complex which was utilized for M. anisopliae by Silveira and Azevedo (1987) and by Hamlyn et al. (1981) to obtain protoplasts from several other species of fungi, was also efficient for protoplast production in M. flavoviride. Other authors (Silveira and Azevedo, 1987; Shimuzu and Kurisu, 1987; Bagalhi, 1987) using strains of $M$. anisopliae found protoplast production values similar to the ones obtained in the present work. No statistically significant differences were observed for protoplast production from the four strains used in this research. Novozyn 234 was effective for protoplast liberation in M. flavoviride. Some authors used more than one enzymatic complex, also with good results. For example, Valadares-Inglis and Inglis (1997) attempting to develop a genetic transformation system for M. flavoviride, used the Novozym 234 plus Cellulase $\mathrm{CP}$ to obtain protoplasts. The percentages of protoplast regeneration values, although varied according to the strains, being more effective for the colour mutant strains when compared to the wild-type ones, were in agreement with those found by Paccola-Meirelles and Azevedo (1994) in the entomopathogenic fungus Beauveria bassiana. On the other hand, the values were higher than those obtained by Silveira and Azevedo (1987) for M. anisopliae, which used also $\mathrm{KCl}$ as osmotic stabilizer. However, Bagalhi (1987) found that sugars as, for instance, sacarose increased the percentage of protoplasts regeneration in $M$. anisopliae. It is possible that increased percentages of regeneration may also be reached in $M$. flavoviride using other osmotic stabilizers as sugars.

Table 2 - Number of formed protoplasts and percentages of protoplast regeneration $\left({ }^{*} \sigma\right)$. The different letters, in same column, indicate values significantly different $(\mathrm{P}<$ $0.05)$ as determined by Tukey's test.

\begin{tabular}{c|cc|cc}
\hline Strain & \multicolumn{2}{|c|}{$\begin{array}{c}\text { Protoplasts } \times \mathbf{m L}^{-1} \\
(* \boldsymbol{\sigma})\end{array}$} & $\begin{array}{c}\% \text { regeneration } \\
(* \boldsymbol{\sigma})\end{array}$ \\
\hline CG423 & $5.10 \times 10^{6}$ & $(0.18)^{\mathrm{a}}$ & 6.65 & $(0.98)^{\mathrm{a}}$ \\
423ylo & $6.95 \times 10^{6}$ & $(0.22)^{\mathrm{b}}$ & 9.80 & $(0.84)^{\mathrm{b}}$ \\
CG366 & $1.15 \times 10^{7}$ & $(0.38)^{\mathrm{c}}$ & 10.96 & $(0.41)^{\mathrm{c}}$ \\
366vio & $5.05 \times 10^{6}$ & $(0.42)^{\mathrm{a}}$ & 27.92 & $(0.17)^{\mathrm{d}}$ \\
\hline
\end{tabular}

During the process of protoplast regeneration, we found an unexpected occurrence of morphological variant colonies derived from one of the strains (CG423). These variants that presented $6.57 \%$ of frequency, were stable and maintained the morphological features after several transfers. Similar findings are common after regeneration of protoplasts for Streptomyces (Araújo, 1990). However, there are no reports of such occurrence during protoplast regeneration in filamentous fungi. All morphological mutants found had compact circular colonies with pale yellow conidia, which were difficult to disperse and also produced yeast-like structures in solid medium. They differed from the parental strain that produced easily dispersed green conidia, colonies with powdery aspect and which did not form yeast-like structures in solid medium. The formation of yeast-like structures in filamentous fungi occurred very frequently in submerged cultures, but it was rare on solid medium (Humphreys et al., 1989; Luna-Alves-Lima and Tigano, 1989).

Strains CG423 (wild-type) and one morphological mutant, designated 423PR obtained from regenerated protoplasts, were analyzed for sensitivity to the fungicides benomyl and captan (Figs. 1 and 2). The 423PR strain was more sensitive to benomyl than the parental strain, but no differences were found in relation to resistance to captan.

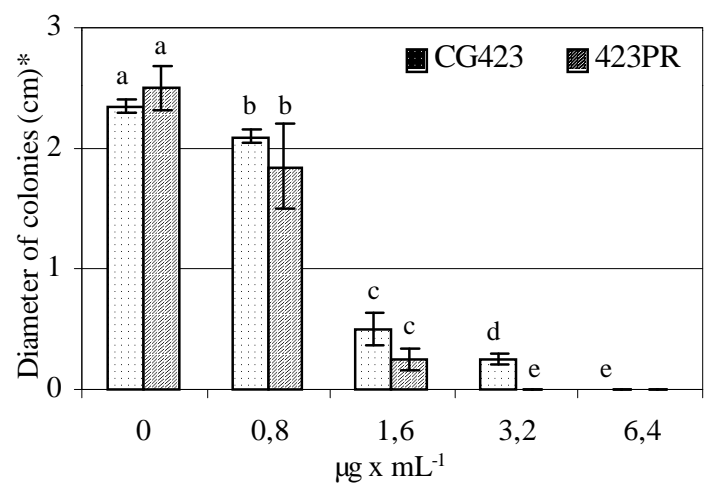

Figure 1 - Sensitivity of Metarhizium flavoviride strains CG423 and 423PR to Benomyl. *Average of three repetitions. The bars indicate the standard deviation and different letters indicate values significantly different $(\mathrm{P}<0.05)$ as determined by Tukey's test. 
Possible causes leading production of morphological mutants during the regeneration of protoplasts are unknown. Martins et al. (1999) found virus associated to strain CG423. If during protoplasts production the virus was lost or even some heterogeneous families of citoplasmic inclusions as mitochondria are quantitatively and qualitatively changed, this may produce the observed morphological differences. Associated to the morphological shifts, changes were also found for resistance to benomyl. The original strain CG423 was able to grow in $3.2 \mu \mathrm{g} \times \mathrm{mL}^{-1}$ but did not formed colonies at $6.4 \mu \mathrm{g} \times \mathrm{mL}^{-1}$ of benomyl. These values of natural resistance to this fungicide were in agreement with data presented by Valadares-Inglis and Inglis (1997) and Furlaneto et al. (1999). On the other hand, the variant strain
423PR could not form colonies in concentrations higher than $1.6 \mu \mathrm{g} \times \mathrm{mL}^{-1}$. Possibly, the altered variant morphology could produce changing in cell permeability making the strain more susceptible to benomyl. If this was the case, tests with other fungicides would produce similar results. In the present work, no significant differences were found for both strains in relation to captan resistance. However, captan proved not to be appropriate for such test since $M$. flavoviride is highly resistant to this fungicide growing till the highest concentration used.

In entomopathogenic fungi resistance to fungicides are important when integrated pest control is used. Fungicide resistance may also be useful as genetic markers for strain isolation and characterization.

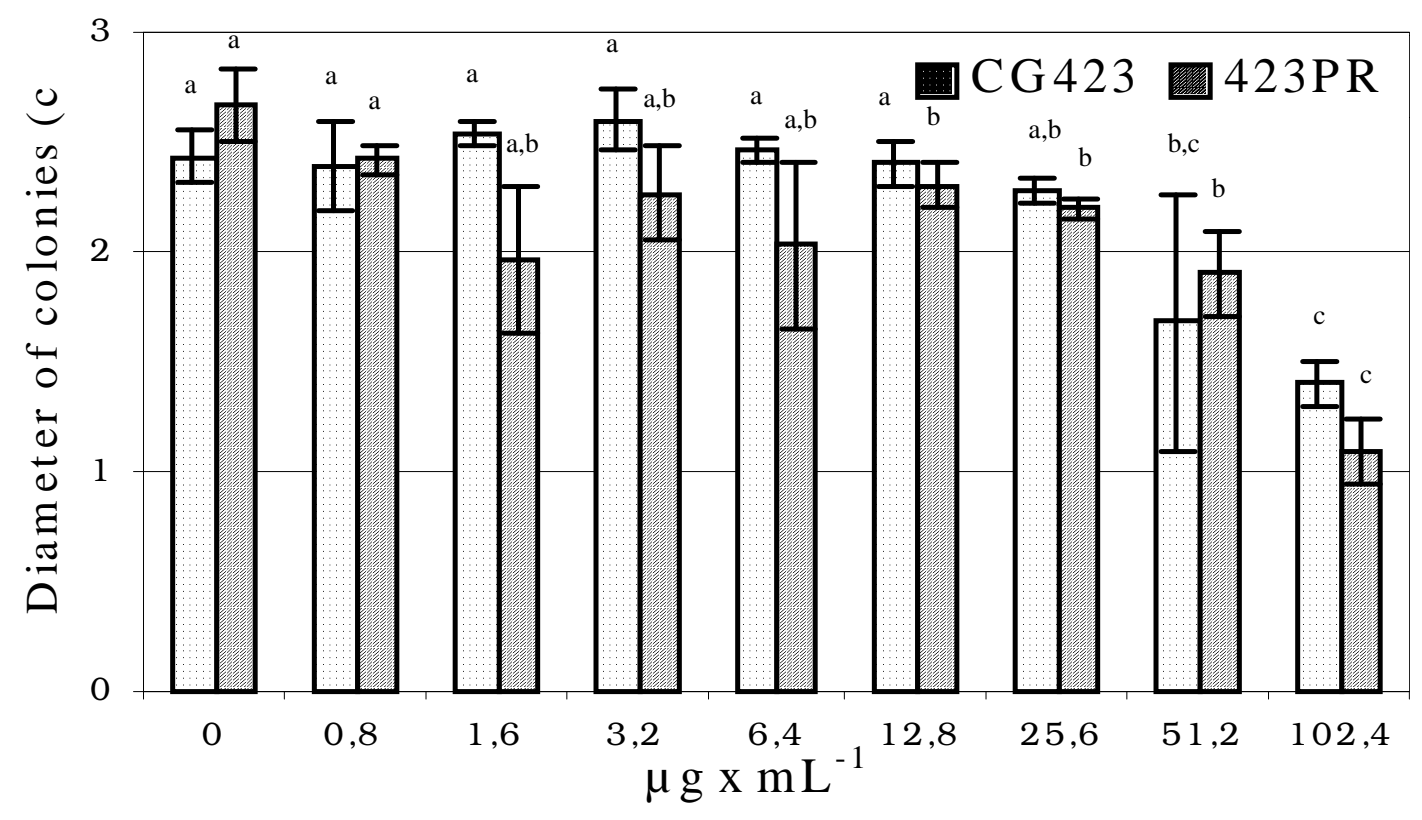

Figure 2 - Sensitivity of Metarhizium flavoviride strains CG423 and 423PR to Captan. *Average of three repetitions. The bars indicate the standard deviation and different letters indicate values significantly different $(\mathrm{P}<0.05)$ as determined by Tukey's test.

\section{ACKNOWLEDGEMENTS}

The authors would like to thank Dr. Welington Luiz Araújo for his help. This research was supported by CAPES, FACEPE and CNPq.

\section{RESUMO}

A formação e regeneração de protoplastos foram avaliadas em duas linhagens selvagens e duas linhagens mutantes para coloração de conídios em Metarhizium flavoviride. $\mathrm{O}$ cultivo em meio líquido seguido do tratamento do micélio com Novozym 234 na presença de $\mathrm{KCl} 0,7 \mathrm{M}$ como 
estabilizador osmótico, resultou na produção de $5,05 \times 10^{6}$ a $1,15 \times 10^{7}$ protoplastos $\times \mathrm{mL}^{-1}$. A porcentagem de regeneração das diferentes linhagens variou de 6,65 a $27,92 \%$. Após a regeneração, uma das linhagens selvagens produziu espontaneamente variantes estáveis, com morfologia alterada. Embora variantes morfológicos já tenham sido observados após regeneração de protoplastos em bactérias, esta parece ser a primeira vez que tal ocorrência é descrita em fungos filamentosos. Um desses variantes, além da linhagem selvagem da qual ele foi originado, foi testado para sensibilidade aos fungicidas benomil e captano.

\section{REFERENCES}

Araújo, J. M. (1990), Plasmídios Conjugativos e Fusão de Protoplastos em Streptomyces felleus. PhD Thesis, Escola Superior de Agricultura "Luiz de Queiroz" Universidade de São Paulo, Piracicaba, SP, Brazil.

Athayde, A. C. R. (2002), Patogenicidade de Beauveria bassiana, Metarhizium anisopliae e Metarhizium flavoviride sobre ovos, larvas e teleóginas de Boophilus microplus da região semi-árida paraibana. $\mathrm{PhD}$ Thesis, Universidade Federal de Pernambuco, Recife, PE, Brazil.

Azevedo, J. L. (1995), Técnicas utilizadas nos processos biotecnológicos envolvendo fungos. Rev. Bras. Bot., 18, 77-87.

Azevedo, J. L. and Costa, S. O. P. (1973), Exercícios Práticos de Genética. Editora Nacional, EDUSP, São Paulo, Brazil.

Bagalhi, E. (1987), Parameiose em Metarhizium anisopliae (Metsch.) Sorokin. Master Thesis, Escola Superior de Agricultura "Luiz de Queiroz", Universidade de São Paulo, Piracicaba, SP, Brazil.

Figueirêdo, R. E. C. R. and Silva, J. C. (2001), Recombination via parasexual cycle in Metarhizium flavoviride. Paper presented at $21^{\text {th }}$ Congresso Brasileiro de Microbiologia, Paraná, Brazil.

Furlaneto, M. C.; Paião, F. G.; Pinto,. F. G. D. and Fungaro, M. H. P. (1999), Transformation of the entomopathogenic fungus Metarhizium flavoviride to high resistance to benomyl. Can. J. Microbiol., 45, 875-877.

Goettel, M. S.; Johnson, D. L. and Inglis, G. D. (1995), The role of fungi in the control of grasshoppers. Can. J. Bot., 73, S71-S75.

Hamlyn, P. F.; Brasdshaw, R. E.; Mellon, F. M.; Santiago, C. M.; Wilson, J. M. and Peberdy, J. F. (1981), Efficient protoplast isolation from fungi using commercial enzymes. Enzyme Microb. Technol., 3, 321-325.
Humphreys, A. M.; Matewele, P.; Trinci, A. P. J. and Gillespie, A. T. (1989), Effects of water activity on morphology, growth and blastospore production of Metarhizium anisopliae, Beauveria bassiana and Paecilomyces farinosus in batch and fed-batch culture. Mycol. Res., 92, 257-264.

Inglis, G. D.; JohnsoN, D. L.; Cheng, K. J. and Goettel, M. S. (1997), Use of pathogen combinations to overcome the constraints of temperature on entomopathogenic hyphomycetes against grasshoppers. Biol. Control., 8, 143-152.

Kuklinsky-Sobral, J. (1999), Variabilidade genética por regeneração de protoplastos e sensibilidade a fungicidas em Metarhizium flavoviride. Master Thesis, Universidade Federal de Pernambuco, Recife, PE, Brazil.

Lomer, C. J; Bateman, R. P.; Johnson, D. L.; Langewald, J. and Thomas, M. (2001), Biological control of locusts and grasshoppers. Ann. Rev. Entomol., 46, 667-702.

Luna-Alves-Lima, E. A. and Tigano, M. S. (1989), Citologia das estruturas leveduriformes de Beauveria bassiana em meios de cultura líquidos e na hemolinfa de Spodoptera frugiperda. Rev. Microbiol., 20, 85-94.

Magalhães, B. P.; Faria, M.; Tigano, M. S. and Sobral, B. W. S. (1997), Characterization and virulence of a brazilian isolate of Metarhizium flavoviride Gams and Rozsypal (Hyphomycetes). Mem. Entomol. Soc. Can., 171, 313-321.

Martins, M. K.; Furlaneto, M. C.; Sosa-Gomes, R. D.; Faria, M. D. and Fungaro, M. H. P. (1999), Doublestranded RNA in the entomopathogenic fungus Metarhizium flavoviride. Curr. Genet., 36, 94-97.

Muniz, C. M.; Barros, I. A. and Azevedo, J. L. (2001), Isolamento de mutantes, variabilidade genética e parasexualidade no fungo entomopatogênico Metarhizium flavoviride. Paper presented at $9^{\text {th }}$ Simpósio de Iniciação Científica da Universidade de São Paulo, São Paulo, Brazil.

Onofre, S. B. (2001), Variabilidade genética em Metarhizium flavoviride (Gams and Rozspal) produzida via parasexualidade e sua patogenicidade sobre Boophilus microplus (Canastrini, 1887). PhD Thesis, Universidade Federal do Paraná, Paraná, Brazil.

Onofre, S. B.; Miniuk, C. M.; Barros, N. M. and Azevedo, J. L. (2001a), Pathogenicity of four strains of entomopathogenic fungi against the bovine tick Boophilus microplus. American J. Vet. Res., 63, 1478-1480.

Onofre, S. B.; Miniuk, C. M.; Fungaro, M. H. P.; Barros, N. M. and Azevedo, J. L. (2001b), Variabilidade genética em recombinates de Metarhizium flavoviride var. flavoviride obtidos via parassexualidade. Paper presented at $21^{\text {th }}$ Congresso Brasileiro de Microbiologia, Paraná, Brazil. 
Paccola-Meirelles, L. D. and Azevedo, J. L. (1994), Genetic recombination by protoplast fusion in the deuteromycete Beauveria bassiana. Braz. J. Genet., 17, 15-18.

Shimizu, S. and Kurisu, K. (1987), Production and reversion of protoplasts from Metarhizium anisopliae. Trans. Mycol. Soc. Japan, 28, 325-330.

Silveira, W. D. and Azevedo, J. L. (1987), Protoplast fusion and genetic recombination in Metarhizium anisopliae. Enzyme Microb. Technol., 9, 149-152.

Valadares-Inglis, M. C. and Inglis, P. W. (1997), Transformation of the entomopathogenic fungus, Metarhizium flavoviride strain CG423 to benomyl resistance. FEMS Microbiol. Lett., 155, 199-202.

Received: June 20, 2002; Revised: October 30, 2002; Accepted: May 14, 2003. 